International Review of Research in Open and Distributed Learning Volume 18, Number 3

May - 2017

\title{
Approaches Reflected in Academic Writing MOOCs
}

\author{
Subeom Kwak \\ The Ohio State University
}

\begin{abstract}
Since it was first introduced in 2008, Massive Open Online Courses (MOOCs) have been attracting a lot of interest. Since then, MOOCs have emerged as powerful platforms for teaching and learning academic writing. However, there has been no detailed investigation of academic writing MOOCs. As a result, much uncertainty still exists about the differences of writing MOOCs compared with traditional types of writing instruction in the classroom. Drawing on historical emphases in writing instruction, five approaches are illustrated: skills, creative writing, process, social practice, and a socio-cultural perspective. This study uses data from six academic writing MOOCs to examine what approaches are revealed within their writing instructions. Focusing on a group of six academic writing MOOCs at college level, attributes and features of writing MOOCs were explored by analyzing syllabi, video lectures, and assignments. Overall, the study found that these academic writing MOOCs stick to a traditional model of teaching writing, "writing as skills." These findings suggest that instructors who teach academic writing through online platforms showed that their immediate concerns were not a social practice or socio-cultural context. Rather, teaching and learning of grammatical accuracy and surface features of texts at college level appear to be best purpose of academic writing MOOCs.
\end{abstract}

Keywords: MOOC, approaches, first-year composition, writing, online writing instruction

\section{Introduction}

I still vividly remember when Daphne Koller, in 2012 at TEDGlobal, explained how she was inspired to create Coursera, which opened doors to people around the world to take great online courses from prestigious universities for free. Now, needless to say, Massive Open Online Courses (MOOCs) have emerged as powerful platforms for teaching and learning of knowledge in various fields (Chen, 2014). When it comes to writing instruction, the growing number of online writing courses has become a central issue for their possibilities to change the landscape of current writing instruction, as well as for the influences of technologies on writing courses and students' literacy.

Investigating writing instruction is a continuing concern within the literacy education field because students at secondary and post-secondary levels still do not have enough opportunities to learn and 
practice writing (Applebee \& Langer, 2013). In recent years, consequently, researchers have shown an increased interest in writing instruction that occurs over the Internet (Hewett \& DePew, 2015; Rendahl \& Breuch, 2013; Warnock, 2009).

The aim of this paper is to identify the approaches reflected on academic writing MOOCs. Syllabi, textbooks, articles, and assignments of writing MOOCs were explored and a discussion on how approaches might help us grasp the complex phenomenon of writing MOOCs was carried out. The fundamental reason for this research is to understand differences between writing MOOCs and a traditional form of teaching writing in a face-to-face setting. Against this backdrop, two research questions are central for the exploration of writing MOOCs:

1. What approaches are revealed within the teaching methods in writing MOOCs?

2. How are these approaches reflected in writing MOOCs' notions of "good" writing?

In this paper, I argued that the "writing skills" approach, a traditional teaching model of writing, is still the most dominant among writing MOOCs, even though different writing approaches have emerged and have been discussed. This is important because the findings represent that writing MOOCs still focus on teaching and learning textual structures, rather than addressing a broader view of written language, such as social contexts, even though there are various writing theories. I illustrated the instructional contexts of writing MOOCs through a case study of academic writing courses provided by six universities, looking in particular at the data related to syllabi, teaching and learning materials, and video lectures.

\section{Theoretical Framework}

This study falls within the range reported in several previous studies on writing approaches reflected in writing instructions, assignments, and other materials (Newell, Beach, Smith, \& VanDerHeide, 2011; Newell, VanDerHeide, \& Olsen, 2014; Newell, Bloome, \& Hirvela, 2015). According to Nystrand (2006), from 1900 to the 1970s, a great deal of previous research into writing has focused on the textual features of exemplary written texts. From this traditional perspective, five-paragraph themes, one introductory paragraph, three body paragraphs, and one concluding paragraph, are used extensively by teachers at secondary level. In post-secondary contexts, in the same way, writing instructions tended to focus on linguistic mechanics, rules, and forms (Lucas, 1955; Strunk \& White, 1959; Warriner, 1950).

Since the 1990s, students have engaged in more opportunities to write, even though the main focus of teaching writing has not changed. Up until now, teachers usually teach students how to write fiveparagraph themes under the name of the Hamburger Essay, a one-three-one, or a three-tier essay (Hillocks, 2002). Teaching writing five-paragraph themes was very controversial (Johnson, Thompson, Smagorinsky, \& Fry, 2003; Wesley, 2000), but it is still one of the dominant foci of teaching writing (Campbell \& Latimer, 2012).

From the 1960s, a cognitive perspective has helped researchers to determine which strategies would be effective for students. For instance, in 1971, Emig examined writing as a cognitive process, analyzing 
Harvard professors' writing styles and $12^{\text {th }}$ grade students in the northern area of Chicago. The study had a major impact on research trends on writing as a process. To date, it is a widely held view that Emig (1971) was the first to suggest writing as a process, even though Nystrand (2006) questioned it because there are prior studies regarding writing as a process (e.g., Young \& Becker, 1965).

Functioning as a framework for designing experimental and quasi-experimental research, a cognitive perspective has specified effective ways of teaching writing for students. Researchers also started to focus on audience goals based on the cognitive process model (Hayes \& Flower, 1980). For example, Sexton, Harris, and Graham (1998) identify the effect of different audience goals by experimental research.

Yet a cognitive perspective has overlooked the importance of social context (Newell et al., 2011). Without consideration of the social contexts and students' knowledge of social dynamics, the effectiveness of writing instruction would be difficult to address, and will raise validity issues. Furthermore, without considering the social context, experimental research grounded in a cognitive perspective has a tendency to focus on text production, and fails to address new knowledge construction through social interaction.

"Social practice" is an ambiguous term because it is used in so many different contexts. It is defined here as a shared way of doing something within specific contexts, which is also connected to other social practices (Baynham, 1995; Street, 2014). Social practice is not a sole behavior isolated from context. A classroom, of course, has its own shared way of approaching social relationships and constructions during teaching and learning (Newell et al., 2015). "Sociocultural perspective" has a broader view than social practice in that this view would consider various factors beyond the place where writing occurs.

In a meta-analysis of previous research and theories of writing and writing instruction, Ivanič (2004) identifies six discourse frameworks: a skill, creativity, a process, a genre, social practices, and sociopolitical discourses. These discourses showed different ways of conceptualizing the teaching and learning of writing. Defining "discourses of writing" as "constellations of beliefs about writing, beliefs about learning to write, ways of talking about writing, and the sorts of approaches to teaching and assessment which are likely to be associated with these beliefs" (Ivanič, 2004, p. 224), Ivanič (2004) discusses how these could be used as a framework in literacy research.

Again, Behizadeh and Engelhard (2011) suggested a conceptual framework for writing research by discussing research traditions in measurement and writing theories to grasp their influences on writing assessments during the $20^{\text {th }}$ century in the United States. The historical review of writing research by Behizadeh and Engelhard (2011) offers probably the most comprehensive framework for a full understanding of the practices of teaching writing. To capture and understand current phenomena of writing MOOCs, a revised conceptual framework was developed from the perspectives of Ivanič (2004) and Behizadeh and Engelhard (2011). The revised conceptual framework for this research is presented in Table 1 below. 
Table 1

Revised Conceptual Framework for Writing Instruction

\begin{tabular}{|c|c|c|}
\hline Approaches & $\begin{array}{l}\text { Focus of teaching and } \\
\text { learning }\end{array}$ & $\begin{array}{l}\text { Focus of research and } \\
\text { theoretical perspective }\end{array}$ \\
\hline Writing as a skill & $\begin{array}{l}\text { Textual features, forms, and } \\
\text { correctness }\end{array}$ & Textual analysis \\
\hline Creative writing & $\begin{array}{l}\text { Interesting content and style, } \\
\text { enjoyment of literature, self- } \\
\text { expression }\end{array}$ & $\begin{array}{l}\text { Textual analysis } \\
\text { Cognitive perspective }\end{array}$ \\
\hline Writing as a process & $\begin{array}{l}\text { Cognitive and practical process } \\
\text { of writing }\end{array}$ & $\begin{array}{l}\text { Cognitive psychology } \\
\text { Cognitive perspective }\end{array}$ \\
\hline Writing as a social practice & $\begin{array}{l}\text { Social interactions between } \\
\text { teacher and students, writing } \\
\text { event, writing according to } \\
\text { social contexts }\end{array}$ & $\begin{array}{l}\text { Ethnography } \\
\text { Social practice perspective }\end{array}$ \\
\hline Writing in a socio-cultural context & $\begin{array}{l}\text { Broader contexts of writing, } \\
\text { social forces, power relations, a } \\
\text { critical awareness }\end{array}$ & $\begin{array}{l}\text { Mixed methods } \\
\text { Social practice perspective }\end{array}$ \\
\hline
\end{tabular}

The first column lists the five types of conceptualization of writing that are used to analyze writing MOOCs in the main section of this paper. The next column represents the main focus of the teaching and learning of writing. These classified foci are not necessarily neatly compartmentalized because different approaches could have some commonalities and overlapping characteristics in some ways. Ivanič (2004) and Behizadeh and Engelhard (2011) also pointed out their difficulties in distinguishing an approach among others due to overlapping characteristics.

Writing as a skill perspective assumes that writing is a unitary behavior in decontextualized contexts. In this view, teachers expect their students to apply what they learned into new writing tasks, regardless of text type or context. What counts as good writing in this perspective is tied to the correctness of linguistic forms (Lunsford, 1986). What counts as good writing does not change from context to context, thus students are expected to reproduce accurate or proper linguistic patterns. Learning to write consists of learning the mechanics, correct usages, and formal features of academic writing explicitly. In the practice of teaching based on writing as a skill approach, writing is usually taught as an isolated set of skills, rather than an integration of reading.

A creative writing approach emerged as a response to the necessity of expanding the scope of writing, looking for critical, imaginative, and creative activities. For instance, Searles and Carlsen (1960) reported limits on writing as a skill perspective and argued that writing instruction should be changed in order to widen or shift from static forms of language to creativity. From the perspective of creative writing, teachers emphasized the importance of "meaning" rather than the correctness of linguistic forms because writing is used as a tool for the enjoyment of literature. In fact, considering many language arts teachers are teachers of literature, this is not a surprising phenomenon. Therefore, writing activity is valued as it is in the meaning-making process. Contrary to writing as a skill approach, in this view, students often learn how to write implicitly by reading exemplary texts by others as a model. This view of writing values 
learners' voices, and what counts as good writing, is determined by criteria borrowed from the field of literature.

In writing as a process approach, three stages of compositing processes became central: planning, drafting, and revising. Along with these compositing processes, individual cognitive processes have also attracted researchers' attention (Flower \& Hayes, 1980). As mentioned above, this is important because researchers began to pay more attention to processes of writing instead of the text as a final product. As a reflection of this approach, a growing number of teachers began to adopt this method for their writing instructions, and indeed this approach has become popular since the 1980s. From this perspective, learning to write involves learning what to do in each stage of composing processes explicitly (Behizadeh \& Engelhard, 2011).

During the 1970 s and 1980s, while numerous studies have attempted to explain writing as a process, writing as a social practice perspective was also emerging. From the perspective of writing as a social practice, the teaching and learning of writing cannot be conceptualized in decontextualized settings (Heath, 1983; Street, 1984). Writing is conceptualized as a purpose-driven written communication, and different social practices could have an influence on writing practice (Ivanič, 2004). In this view, the main weakness of writing as a process and writing as a skill approaches is the failure to consider social contexts.

Specifically, classroom culture, interaction between a teacher and students, patterns of assigning writing tasks, space, and resources have been observed and analyzed from the ethnographic perspective to explain teaching and learning writing. Writing as a social practice is, thus, not a formulaic matter in decontextualized settings. From writing as a social practice approach, learning to write encompasses understanding the nature of writing implicitly by participating in communities of writing practices.

Writing in a socio-cultural context approach is also focused on the context of writing. With this regard, this view and writing as a social practice become somewhat blurred. However, in contrast to writing as a social practice that concerns the context writing in which occurs, writing in a socio-cultural perspective focuses on the wider aspects of writing activity and contexts. For instance, how social forces, power relations, or an author's identity could shape writing practices would be the main interests in writing in a sociocultural context perspective. To be more specific, in this view, student writing abilities are not only explained by student papers or teacher's feedback within a classroom context, but also by cultural backgrounds, community, a student's life, and home practices.

The primary focus of this study is on the writing MOOCs. Writing MOOCs that draw on the conceptual framework described above as the foundation of generating a coding frame were explored. Subcategories of a coding frame were generated to specify different attributes of writing approaches. More specifically, the study identifies what approaches were adopted in six different writing MOOCs. This limited number of writing courses were selected to investigate certain characteristics of "academic" writing MOOCs. What follows is a discussion of related research and the specific methods used for this study. 


\section{Related Research}

Although a large number of learners have taken writing MOOCs, a search of the literature revealed few studies have investigated this topic. For instance, a Google Scholar search using "writing MOOC" and "writing MOOCs" yields fewer than 25 and 50 hits, respectively. Unfortunately, looking closer, most of them are not closely associated with writing MOOCs; almost all papers are conference proceedings and broader views of MOOC pedagogies. However, educational researchers and literacy scholars also recognize the need for a scholarly exploration of teaching and learning writing through MOOCs (Comer \& White, 2016; Griffin \& Minter, 2013; Suen, 2014). Research is needed to improve our understanding of writing MOOCs, especially given the current demands and trends for teaching and learning through MOOCs. Yet few studies have investigated writing MOOCs in any systematic way, with much less research on academic writing MOOCs at university level (Hewett, 2015).

Reflecting on how the Rhetorical Composing MOOC was re-edited and re-recorded with a new understanding of writing MOOCs, Halasek et al. (2014) reported that their assumptions had been challenged continuously by the realities of the writing course: participants, online discussion forums, and different roles as teachers. After describing how their writing MOOCs reshaped and reframed their questions and understanding, Halasek et al. concluded, "it's still premature to make definitive claims about how (or how effectively) MOOCs will transform the teaching of writing” (2014, p. 165). This study suggests that teachers' underlying assumptions and reframed understanding may have an immediate influence on what instructional plans teachers designed.

Recently, Comer and White (2016) shared their experience of designing writing assessments in academic writing MOOCs. They identified three categories of challenges to writing MOOCs: the absence of an available model for writing MOOCs; decontextualized writing assessments; and difficulty of disciplinebased writing assessments. A key finding was that although many learners failed to achieve the learning objectives, some learners reflected on themselves as writers, gained writing skills, and raised awareness of global audiences. Comer and White (2016) suggested that writing MOOCs could be a post-secondary educational initiative with well-planned assignments, criteria, and timely support. This suggestion confirmed the need for extra training of instructors for teaching in online settings (Griffin \& Minter, 2013).

While these studies provide important insights into the landscape of writing MOOCs, their investigations are not developed within a conceptual framework for writing instruction. Nor do these studies comparatively analyze the teaching of academic writing among different writing MOOCs. Beyond the few studies reviewed here, there is also a prevailing tendency in MOOC research to view writing MOOCs as a static, rather than dynamic, process among various courses in different disciplinary communities and institutions. Against this backdrop, this research is a story of an ongoing exploration of writing MOOCs, and an effort to illustrate the current landscape of writing MOOCs for the teaching and learning of academic writing. 


\section{Research Methods}

The aim of this study was to investigate how instructors of MOOCs teach academic writing. This study relied on data from video lectures, syllabi, assignments, and related materials. I found 50 writing MOOCs and selected only six courses with the exclusion/inclusion criteria for this study (see Appendix A for details of the search). Six writing courses were gathered and analyzed from Coursera, EdX, and Futurelearn. As shown in Table 2, the video lectures averaged 365 minutes, with a range of 40 minutes to over 12 hours. The 40 minute course was considerably shorter than all others in the group, with the next shortest being 145 minutes. The universities providing the online writing courses include large research universities and smaller regional universities in the United States, and a public university in the United Kingdom (all institutions' names are pseudonyms).

Table 2

Data Sources for the Six Writing MOOCs

\begin{tabular}{lllllll}
\hline Sources of data & Elite Coll. & Res. U & State U & Urban U & Ind. U & Collab. U \\
\hline Video lectures & 752 & 285 & 304 & 40 minutes & 667 & 145 minutes \\
& minutes & minutes & minutes & & minutes & \\
Assignments & 2 & 4 & 6 & 1 & 7 & 9 \\
Syllabus & 1 & 1 & 1 & 1 & 1 & 1 \\
Artifacts & 4 & 4 & 151 & 32 & 18 & 48 \\
$\begin{array}{l}\text { (e.g., } \\
\text { instructional }\end{array}$ & & & & & & \\
materials, \\
external sources, \\
and quiz)
\end{tabular}

\section{Coding Video Lectures}

Once video lectures had been collected from six writing MOOCs, we set out to code the videos to identify commonalities and differences among the writing MOOCs. Coders had to infer the underlying assumptions and knowledge from statements by the instructors. In our first cycle of coding, we used the descriptive coding method (Saldaña, 2016) because descriptive coding is useful for analyzing the data's basic topics to assist with answering the general question, "What is going on here?" Our early attempts at coding video lectures of one of six courses resulted in $88 \%$ exact agreement between two coders. However, as we proceeded, our attempts at coding had very low agreement, as low as $55 \%$. In addition, exploring video lectures by coding, we grasped the categorization of data, but were not fully satisfied because we began to question whether the subcategories mutually excluded each other.

Consequently, our first cycle of descriptive coding became the basis for a second cycle of coding for more exact agreement. We often discovered that there was some conceptual overlap between categories-more than we had expected. When we disagreed on any item, we resolved disagreements through much rearrangement and reflection on our coding frame. This procedure turned out to be very time-consuming but worth the effort to produce an accurate coding frame. On this second round of coding, all disagreements were resolved with the revised coding frame. 
In the third round of coding, to assess the reliability of a coding frame, each coder used the same coding frame to analyze the video lecture transcripts a week after the second round. This comparison across two points in time confirmed that the coding frame was reliable as the results remained stable (Schreier, 2012).

Table 3

Cross-Course Comparison

\begin{tabular}{|c|c|c|c|c|c|c|c|c|c|c|c|c|}
\hline \multirow{3}{*}{ Code } & \multicolumn{2}{|c|}{$\begin{array}{l}\text { Elite } \\
\text { Coll. }\end{array}$} & \multicolumn{2}{|c|}{ Res. U } & \multicolumn{2}{|c|}{ State U } & \multicolumn{2}{|c|}{ Urban U } & \multicolumn{2}{|c|}{ Ind. U } & \multicolumn{2}{|c|}{$\begin{array}{c}\text { Collab. } \\
\mathbf{U}\end{array}$} \\
\hline & No & $\%$ & No & \% & No & \% & No & $\%$ & No & \% & No & $\%$ \\
\hline & . & & . & & . & & . & & . & & . & \\
\hline Writing as a skill & & & & & & & & & & & & \\
\hline Textual features & 182 & 26 & $\begin{array}{l}25 \\
0\end{array}$ & 87 & 116 & 40 & 14 & 28 & 60 & 9 & 60 & 43 \\
\hline Accuracy & 78 & 11 & - & - & 16 & 6 & 10 & 20 & 20 & 3 & 10 & 7 \\
\hline Structures & 299 & 43 & 20 & 7 & 116 & 40 & 10 & 20 & 140 & 22 & 30 & 21 \\
\hline Creative writing & - & - & - & - & - & - & - & - & 10 & 2 & - & - \\
\hline Writing as a process & & & & & & & & & & & & \\
\hline Peer/Tutor review & - & - & - & - & - & - & 4 & 8 & 120 & 19 & 20 & 14 \\
\hline Strategies & 5 & 9 & - & - & 24 & 8 & 8 & 16 & 210 & 33 & 15 & 11 \\
\hline Writing as a social practice & & & & & & & & & & & & \\
\hline Social interactions & - & - & - & - & - & - & - & - & 10 & 2 & 5 & 4 \\
\hline Writing event & - & - & - & - & - & - & - & - & 10 & 2 & - & - \\
\hline Social contexts & 13 & 2 & 10 & 4 & - & - & - & - & 20 & 3 & - & - \\
\hline $\begin{array}{l}\text { Writing in a socio-cultural } \\
\text { context }\end{array}$ & & & & & & & & & & & & \\
\hline Broader context of writing & 13 & 2 & - & - & - & - & - & - & 10 & 2 & - & - \\
\hline Critical awareness & - & - & - & - & - & - & - & - & 20 & 3 & - & - \\
\hline Reflection & 52 & 7 & - & - & 4 & 2 & 2 & 4 & 10 & 2 & - & - \\
\hline Announcement & - & - & 5 & 2 & 12 & 4 & 2 & 4 & - & - & - & - \\
\hline
\end{tabular}

Note. All percentages were rounded using the convention of rounding up for .5 and greater, and rounding down for percentages lower than .5. The \# columns refer to the approximate frequencies with which video lectures attributed their teaching to particular approaches. The \% columns refer to the approximate percentage of the total codes for that category.

\section{Analysis of Materials}

For the analysis of syllabi, each syllabus was read three times. For the first reading, analytic memos were taken to gather initial impressions from the required books, articles, and assignments to carefully identify their overall structure and teaching methods the syllabi revealed. First reading of the syllabi revealed that the investigation should be extended to the next three features: the approaches to teaching writing in online contexts, the types of assignments/tasks for students to learn academic writing, and what approaches are reflected on these online writing instructions. 
To explore these three features of writing MOOCs, during the second reading of the syllabi, the required/recommended textbooks or articles were evaluated, while video lectures and writing assignments were analyzed in order to grasp the instructors' concerns and ideals regarding their writing instruction. Drawing on the theoretical framework as discussed in the previous section, each writing course or section of a writing course were classified by their approaches to teaching writing on the basis of analysis of video lectures, syllabi, and assignments. The third reading of the syllabi was to finalize categorizations and focus on the extent to which the differences between these online and traditional courses are emerging; to tie up the loose ends. This research was not designed to identify the effectiveness of writing instructions but to examine the writing instruction itself and approaches reflected within it. Analysis of pre- and post-tests of students' writing was not a part of this research.

\section{Results and Discussion}

In this paper, I argued that writing MOOCs have strong tendencies to adhere to a traditional model of teaching and learning of writing, "writing as skills." This is important as these findings show most current writing MOOCs still focus on teaching and learning textual structures, and rely on traditional methods of teaching writing, despite various writing theories. A considerable amount of literature has revealed the phenomena that the practices of teaching writing in face-to-face settings are far removed from writing theories or research (Aull \& Lancaster, 2014; Crossley, Roscoe, \& McNamara, 2014; Doolan, 2014; Hanauer, 2015; Imbrenda, 2016). It can thus be suggested that the same phenomena were founded in writing MOOCs.

Table 4

Courses' Goals, Beliefs, and Assessment for Approaches

\begin{tabular}{|c|c|c|c|c|c|c|}
\hline & Elite Coll. & Res. U & State U & Urban $\mathbf{U}$ & Ind. U & Collab. U \\
\hline Approach & $\begin{array}{l}\text { Writing as } \\
\text { a skill }\end{array}$ & $\begin{array}{l}\text { Writing as a } \\
\text { skill }\end{array}$ & $\begin{array}{l}\text { Writing as } \\
\text { a skill }\end{array}$ & $\begin{array}{l}\text { Writing as a } \\
\text { skill }\end{array}$ & $\begin{array}{l}\text { Writing as } \\
\text { a process }\end{array}$ & $\begin{array}{l}\text { Writing as a } \\
\text { skill }\end{array}$ \\
\hline Goals & $\begin{array}{l}\text { Editing } \\
\text { and } \\
\text { revising } \\
\text { drafts for } \\
\text { better } \\
\text { sentences } \\
\text { and } \\
\text { paragraphs }\end{array}$ & $\begin{array}{l}\text { Effective } \\
\text { composition } \\
\text { of alphabetic, } \\
\text { visual, and } \\
\text { multimodal } \\
\text { texts }\end{array}$ & $\begin{array}{l}\text { Conductin } \\
\text { g academic } \\
\text { research } \\
\text { and to } \\
\text { express } \\
\text { ideas } \\
\text { clearly in } \\
\text { an } \\
\text { academic } \\
\text { format }\end{array}$ & $\begin{array}{l}\text { Writing with } \\
\text { good } \\
\text { academic } \\
\text { style } \\
\text { focusing on } \\
\text { grammar }\end{array}$ & $\begin{array}{l}\text { Examinin } \\
\mathrm{g} \text { the } \\
\text { stages of } \\
\text { the } \\
\text { writing } \\
\text { process }\end{array}$ & $\begin{array}{l}\text { Learning } \\
\text { about } \\
\text { defining and } \\
\text { supporting } \\
\text { an important } \\
\text { belief in } \\
\text { writing }\end{array}$ \\
\hline Beliefs & $\begin{array}{l}\text { Principles } \\
\text { of effective } \\
\text { writing in } \\
\text { the fields } \\
\text { of science }\end{array}$ & $\begin{array}{l}\text { Rhetoric as a } \\
\text { framework for } \\
\text { understandin } \\
\text { g different } \\
\text { texts }\end{array}$ & $\begin{array}{l}\text { Writing as } \\
\text { a set of } \\
\text { skills at } \\
\text { college } \\
\text { level }\end{array}$ & $\begin{array}{l}\text { Remedial } \\
\text { English for } \\
\text { learners } \\
\text { from non- } \\
\text { elite } \\
\text { background }\end{array}$ & $\begin{array}{l}\text { Writing } \\
\text { strategies } \\
\text { and } \\
\text { reflection } \\
\text { as a writer }\end{array}$ & $\begin{array}{l}\text { Rhetorical } \\
\text { concepts that } \\
\text { help learners } \\
\text { to } \\
\text { communicat } \\
\text { e effectively }\end{array}$ \\
\hline
\end{tabular}




$\begin{array}{lllllll}\text { Assessment } & \text { Taking } & \text { Creating a } & \text { Conductin } & \text { Writing the } & \text { Analyzing } & \text { Composing a } \\ \text { quizzes, } & \text { plan, } & \text { g research } & \text { first draft in } & \text { a visual } & \text { personal } \\ \text { drafting, } & \text { composing, } & \text { on an } & \text { five- } & \text { image, } & \text { philosophy } \\ \text { peer } & \text { making a } & \text { academic } & \text { paragraph } & \text { developin } & \text { essay, visual, } \\ \text { reviews, } & \text { visual } & \text { topic } & \text { theme } & \text { ga case } & \text { and } \\ \text { and a } & \text { argument, } & & & \text { study, and } & \text { presentation } \\ \text { multiple- } & \text { and peer } & & & \text { writing an } & \\ \text { choice test } & \text { review } & & & \text { op ed } & \end{array}$

\section{Writing as a Skill}

In a writing MOOC provided by Urban University, the book, Grammar for Writing Study Book by Anne Vicary (2014) was selected as the foundation for writing instruction and instructional plans. Needless to say, this book was published to help with understanding and using grammar for accurate English. During the first week of this course, an essay was presented as a sample to be examined and to discuss how to improve the quality of writing. In this sample essay, an instructor spent most of the time pointing out low levels of paragraphing, problems of choosing verbs, and punctuation issues.

Discussing the revision process with the revised sample essay, large portions of the lecture is, again, centered on linguistic forms rather than other areas of writing. In terms of organization, a five-paragraph theme was introduced as an exemplary model, and learners had opportunities to practice writing with this form. The team of instructors continued to stress the importance of grammatical accuracy for good academic writing by teaching different tense and sentence types throughout the third week. Sometimes, they attempted to teach planning and drafting, but most of their suggestions for improvement were focused on grammatical accuracy when discussing a sample essay.

Instructor: Let's take a look at her first mistake. "Most of primary school are begin to teach English.” This should be "most primary schools are beginning to teach English.” We don't need the "of" with "most." And "primary school" should be plural, as she's referring to primary schools in general. Also, she's tried to use the present continuous, but you need I-N-G at the end: "are beginning."

Let's look at the next point. Chaohua wrote, "Some children start to learn English." But again, she's talking about a temporary situation or a changing situation, so she should have used the present continuous here. "Some children are starting to learn English." In the next sentence, she wrote, "It also has many language schools." But she should have put, "There are also many language schools," as she's introducing a new idea.

Likewise, a writing MOOC designed by State University also relied predominantly on writing as a skill approach. This course explicitly showed a strong tendency to emphasize the importance of learning linguistic forms and grammatical accuracy in writing instruction. For instance, before introducing how to plan a research paper, 12 weeks of study, three-fifths of the whole session, were designed for teaching grammar, punctuation, paragraphs, and thesis statements. 
As a final project, learners chose their own research topics, planned, and wrote a 7-8 page paper in accordance with the linguistic rules and forms they learned before. Similarly, no significant differences were found in either course from Collaborative and Research universities, in that both courses also focused on textual features with rhetorical concepts for teaching appropriate forms that would be accepted in university contexts.

Interestingly, Elite College designed a writing course particularly for composing scientific research papers. Yet, further analysis showed that most sessions considered appropriate forms of writing and grammatical accuracy. Grammar and sentences were the main topic of the video lectures. In addition, most quizzes and final examinations consisted of multiple-choice tests for the knowledge of grammar.

\section{Writing as a Process}

The results of this study indicate that five out of six writing MOOCs could be classified into the writing as a skill category. Contrary to these five courses, one writing course by Independent University was more concerned with writing strategies, a reflection on identity as a writer, and different stages of writing, rather than surface features of text. The instructor revealed her view of writing instruction explicitly by stating:

Why is this course not about grammar and syntax? Grammar and syntax are important, but writing is about much more than these elements. Effective writing involves learning how to articulate strong arguments, read closely and critically, engage with the work of others, integrate evidence, and address reader expectations and disciplinary contexts. This course focuses primarily on these elements of writing.

She employed this approach to introduce her students to academic writing in college. Rather than focusing on the text as a final product, she made students reflect on their identity as writers and encouraged them to keep a portfolio of their writings for the course.

I strongly recommend that you create a portfolio of your writing for this course. Include in each copy of your writing projects self-reflections, feedback you have received, and samples of your comments to other writers and your discussion-forum contributions. This material will provide evidence of your accomplishments and help you grow as a writer.

This perspective of learning writing could lead her students to critically think about the ways of writing meaningfully. During the video lectures, it was observed that the instructor made manifest her writing as a process approach through illustrations of the stages of the writing process with integrating quotes, evidence, and feedback. Three writing projects as assignments were given to students in order to grasp the principles of writing as a process by analyzing texts, responding toward revision, and achieving cohesion.

\section{Discussion}

I illustrated that the writing as a skill approach is dominant in current writing MOOCs through an exploration of six academic writing MOOCs at college level. Only one course developed by Independent 
University is more tied to the writing as a process approach. Writing MOOCs from the view of writing as skills tend to emphasize the importance of the correctness of linguistic forms. In the five courses categorized as writing as a skill, writing is usually regarded as a transferable skill. In other words, writing practice was not changed from context to context, and this was the same phenomenon even in the course by Independent University. Thus, students were expected to memorize and reproduce accurate or proper linguistic patterns.

This study of how online writing instructions are shaped by approaches seems to be consistent with other research which found the importance of individual teacher's beliefs, contexts, and constraints (Newell et al., 2014). Considering the context of MOOCs, various student populations from varying educational backgrounds may partly be an external constraint to employ other approaches, such as writing as a social practice or writing in a socio-cultural context. This is because instructors were not able to consider different spectrums of large numbers of student populations when assigning their writing instruction plans.

Is one particular view toward writing MOOCs better than another? Perhaps this is the wrong question to answer. Although, each writing MOOC is categorized based on the theoretical framework discussed, the lines sometimes get blurred. To be more specific, all of the writing MOOCs reflected some attributes of writing as a skill, creative writing, writing as a process, writing as a social practice, and writing in a sociocultural context approach. Thus, one question that could be answered relates to which approach is revealed prominently within each writing MOOC.

Understanding teachers' instructional decisions and the teaching methods is obviously of great importance to writing instruction research (Wilson \& Myhill, 2012). In this study, how instructors' approaches are reflected in their methods of teaching writing through online writing instructions were explored. To investigate approaches to teaching academic writing in MOOCs, an analysis of syllabi, video lectures, and assignments was conducted. In this way, these research findings illustrated differing visions of teaching and learning writing, and how different approaches are reflected in teaching methods. This study will also help in developing awareness of attributes of the writing instruction in MOOCs.

\section{What This Study Adds}

The question for this study is what approaches are revealed within the teaching methods of writing MOOCs. To answer that, we have looked closely at the features of instructors' statements of video lectures in six writing courses. It should be clear by now that these writing courses differ only slightly in that the "writing as skills" approach is the dominant model for teaching writing. It is interesting to note that all six of the writing MOOCs focused on the student's competence to replicate a text type that would be accepted as a scholarly form, rather than the student's raised awareness of the characteristics of a variety of disciplines.

The main purpose of academic writing MOOCs was, needless to say, to teach academic writing. What is, then, academic writing? The fundamental problem behind this question stems from the complexity of understanding academic texts from novice writers' views. After learning academic writing that was based heavily on the "writing as a skill" approach, novice writers may fail to recognize the coherence and 
meaning of writing as a social interaction between writer and reader, fail to grasp how valued text types are socially constructed, and fail to review their own writing practices, which are ideologically shaped. In other words, without an understanding of writing as a social interaction and social construction, novice writers would end up producing texts only to meet the expectations of their instructors. It could be argued that these negative results were due to the main purpose of the writing as a skill approach: training for reproducing an appropriate text type rather than education for preparing for an unpredictable and unknowable future.

The only exceptional case was the Independent University course, which tried to give opportunities for students to become aware of rhetorical flexibility in different disciplinary contexts by offering multiple interviews with scholars from different disciplines, and at least surface features of various disciplinary texts. This is valuable because students could raise their awareness, the variety of their writing, and their consciousness of different demands of writing challenges. However, the limitation of this course was, as discussed above, that it repeatedly and explicitly regarded writing as a transferable skill from context to context. The Independent University course does not differ from other writing courses in that respect. It is my argument here that academic writing MOOCs should, in the end, prepare students for the unpredictable academic challenges that require an understanding and reformulation of textual variety.

\section{Conclusion}

In this investigation, the aim was to uncover the approaches revealed within the teaching methods of writing MOOCs. I argue that most current writing MOOCs at college level rely on a traditional model of teaching writing: writing as a skill. Even during the course developed by Independent University, which showed the writing as a process approach, writing is repeatedly considered as a transferable skill, much like the writing as a skill perspective. When adopting this approach to teach writing, writing instruction is more concerned with the surface level of the textual features of writing. Learning writing means constructing knowledge of grammar, punctuation, and sentences by reproducing exemplary texts. From this perspective, good writing is the reproduction of text with confidence in linguistic forms as a final product that would be accepted in a university setting.

These findings enhance our understanding of the current landscape of writing MOOCs by analyzing six online writing courses at college level. Drawing on a revised theoretical framework as a lens to explore six writing MOOCs, the present study provides additional evidence with respect to the practice of teaching. Several pieces of research indicated that the practice of teaching writing in the classroom is still relying on traditional models of teaching, regardless of the advances or development of writing research or writing theories (Applebee \& Langer, 2013; Behizadeh \& Engelhard, 2011). This study confirms previous findings and contributes additional evidence that suggests writing MOOCs revealed the same phenomenon as the practice of teaching in face-to-face settings. This research provides a framework for the exploration of writing MOOCs. It would be interesting to compare experiences of different individual learners within the same writing MOOC for future research. 


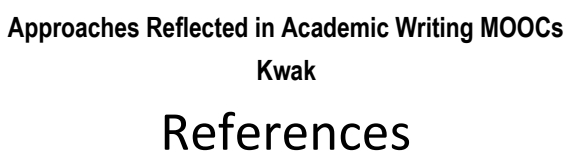

Applebee, A. N., \& Langer, J. A. (2013). Writing instruction that works: Proven methods for middle and high school classrooms. New York: Teachers College Press.

Aull, L. L., \& Lancaster, Z. (2014). Linguistic markers of stance in early and advanced academic writing: A corpus-based comparison. Written Communication, 31(2), 151-183.

Baynham, M. (1995). Literacy practices: Investigating literacy in social contexts. London: Longman.

Behizadeh, N., \& Engelhard, G. (2011). Historical view of the influences of measurement and writing theories on the practice of writing assessment in the United States. Assessing writing, 16(3), 189211.

Campbell, K. H., \& Latimer, K. (2012). Beyond the five-paragraph essay. Portland, ME: Stenhouse Publishers.

Chen, Y. (2014). Investigating MOOCs through blog mining. The International Review of Research in Open and Distributed Learning, 15(2). Retrieved from http://www.irrodl.org/index.php/irrodl/article/view/1695/2884

Comer, D. K., \& White, E. M. (2016). Adventuring into MOOC writing assessment: Challenges, results, and possibilities. College Composition and Communication, 67(3), 318-359.

Crossley, S. A., Roscoe, R., \& McNamara, D. S. (2014). What is successful writing? An investigation into the multiple ways writers can write successful essays. Written Communication, 31(2), 184-214.

Doolan, S. M. (2014). Comparing language use in the writing of developmental generation 1.5, L1, and L2 tertiary students. Written Communication, 31(2), 215-247.

Emig, J. (1971). The composing process of twelfth graders. Champaign, IL: National Council of Teachers of English.

Flower, L., \& Hayes, J. R. (1980). The cognition of discovery: Defining a rhetorical problem. College Composition and Communication, 31(1), 21-32.

Griffin, J., \& Minter, D. (2013). The rise of the online writing classroom: Reflecting on the material conditions of college composition teaching. College Composition and Communication, 65(1), 140161.

Halasek, K., McCorkle, B., Selfe, C. L., DeWitt, S. L., Delagrange, S., Michaels, J., \& Clinnin, K. (2014). A MOOC with a view: How MOOCs encourage us to reexamine pedagogical doxa. In S. D. Krause, \& C. Lowe (Eds.), Invasion of the MOOCs (pp. 156-179). Anderson, South Carolina: Parlor Press.

Hanauer, D. I. (2015). Measuring voice in poetry written by second language learners. Written Communication, 32(1), 66-86. 
Hayes, J. R., \& Flower, L. (1980). Identifying the organization of writing processes. In L. W. Gregg, \& E. R. Steinberg (Eds.), Cognitive processes in writing (pp. 1-17). Mahwah, NJ: Erlbaum.

Heath, S. B. (1983). Ways with words: Language, life, and work in communities and classrooms. Cambridge: Cambridge University Press.

Hewett, B. L. (2015). Grounding principles of OWI. In B. L. Hewett, \& K. E. DePew, (Eds.), Foundational practices of online writing instruction (pp. 33-92). Fort Collins, CO: The WAC Clearinghouse.

Hewett, B. L., \& DePew, K. E. (2015). A Research History of the CCCC OWI Committee. In B. L. Hewett, \& K. E. DePew, (Eds.), Foundational practices of online writing instruction (pp. 5-29). Fort Collins, CO: The WAC Clearinghouse.

Hillocks, G. (2002). The testing trap: How state writing assessments control learning. New York: Teachers College Press.

Imbrenda, J. P. (2016). The blackbird whistling or just after? Vygotsky's tool and sign as an analytic for writing. Written Communication, 33(1), 68-91.

Ivanič, R. (2004). Discourses of writing and learning to write. Language and Education, 18(3), 220-245.

Johnson, T. S., Thompson, L., Smagorinsky, P., \& Fry, P. G. (2003). Learning to teach the five-paragraph theme. Research in the Teaching of English, 38(2), 136-176.

Lucas, F. (1955). Style (2 ${ }^{\text {nd }}$ ed.). London: Cassell.

Lunsford, A. (1986). The past-and future-of writing assessment. In K. L. Greenberg, H. S.Wiener, \& R. A. Donovan (Eds.), Writing assessment: Issues and strategies (pp. 1-12). White Plains, NY: Longman.

Newell, G. E., Beach, R., Smith, J., \& VanDerHeide, J. (2011). Teaching and learning argumentative reading and writing: A review of research. Reading Research Quarterly, 46(3), 273-304.

Newell, G. E., VanDerHeide, J., \& Olsen, A. W. (2014). High school English language arts teachers' argumentative epistemologies for teaching writing. Research in the Teaching of English, 49(2), 95-119.

Newell, G. E., Bloome, D., \& Hirvela, A. (2015). Teaching and learning argumentative writing in high school English language arts classrooms. New York: Routledge.

Nystrand, M. (2006). The social and historical context for writing research. In C. A. MacArthur, S. Graham, \& J. Fitzgerald (Eds.), Handbook of writing research (pp. 11-27). New York: Guilford Press.

Rendahl, M., \& Breuch, L. A. K. (2013). Toward a complexity of online learning: Learners in online firstyear writing. Computers and Composition, 3o(4), 297-314. 
Saldaña, J. (2016). The coding manual for qualitative researchers ( $3^{\text {rd }}$ ed.). London: Sage.

Schreier, M. (2012). Qualitative content analysis in practice. London: Sage.

Searles, J. R., \& Carlsen, G. R. (1960). English. In C. W. Harris (Ed.), Encyclopedia of educational research (pp. 454-470). New York, NY: Macmillan Publishing Company

Sexton, M., Harris, K. R., \& Graham, S. (1998). Self-regulated strategy development and the writing process: Effects on essay writing and attributions. Exceptional Children, 64(3), 295-311.

Street, B. V. (1984). Literacy in theory and practice. Cambridge, UK: Cambridge University Press.

Street, B. V. (2014). Social literacies: Critical approaches to literacy in development, ethnography and education. New York: Routledge.

Strunk, W., \& White, E. B. (1959). The elements of style. New York: Macmillan.

Suen, H. K. (2014). Peer assessment for massive open online courses (MOOCs). The International Review of Research in Open and Distributed Learning, 15(3). Retrieved from http://www.irrodl.org/index.php/irrodl/article/view/1680/2988

Vicary, A. (2014). Grammar for writing study book. Reading, UK: Garnet Education.

Warnock, S. (2009). Teaching writing online: How and why. Urbana, IL: National Council of Teachers of English.

Warriner, J. (1950). English grammar and composition: Complete course. New York: Harcourt Brace Jovanovich.

Wesley, K. (2000). The ill effects of the five paragraph theme. The English Journal, 9o(1), 57-60.

Wilson, A., \& Myhill, D. A. (2012). Ways with words: teachers' personal epistemologies of the role of metalanguage in the teaching of poetry writing. Language and Education, 26(6), 553-568.

Young, R., \& Becker, A. (1965). Toward a modern theory of rhetoric: A tagmemic contribution. Harvard Educational Review, 35, 450-468. 


\section{Search Plan and Inclusion/Exclusion Criteria}

To allow a systematic and exhaustive search, we established the following search plan and specific pre-set criteria for searching academic writing MOOCs.

Table A1

Writing MOOCs Search Plan

\begin{tabular}{ll}
\hline Scope & English L1 settings such as the United Kingdom, the United States, Canada, \\
& Australia, and New Zealand \\
Focus & First year composition/academic writing at university level \\
Limits: Language & English \\
Limits: Type & Non-profit \\
Exclusion & $\begin{array}{l}\text { Adults or further education (vocational or technical) } \\
\text { or secondary level } \\
\text { or English as a second language } \\
\text { or foreign language } \\
\text { or commercial }\end{array}$ \\
\hline
\end{tabular}

Identified writing courses that were of possible relevance for this study were screened using the explicit inclusion and exclusion criteria (see table below). The first screening process was completed on the basis of abstracts and introductions of each course.

Table A2

Second Stage of Inclusion and Exclusion

\begin{tabular}{ll}
\hline Scope & $\begin{array}{l}\text { - Include a focus on the English-speaking context, in which English is } \\
\text { the only language of instruction } \\
\text { - Include courses for teaching L1 writing }\end{array}$ \\
\hline Exclude 1: & $\begin{array}{l}\text { - If concerned with higher education contexts in countries speaking languages } \\
\text { other than English }\end{array}$ \\
\hline Exclude 2: & - If not focused on students who experience higher education \\
\hline Exclude 3: & - If not concerned with academic writing in university settings \\
\hline Exclude 4: & - If not concerned with all or part of the higher education level range \\
\hline Exclude 5: & - If not delivered in English \\
\hline
\end{tabular}

The second stage of screening was undertaken on the basis of each course's syllabus so that irrelevant courses could be excluded. Then the third screening process was conducted based on employed methodology (see table below).

Table A3

Third Stage of Inclusion and Exclusion 


\section{The in-depth review included those studies that met all the following criteria:}

- had predominantly focused on home students in higher education

\section{Studies were excluded if they met one of the following criteria:}

- had more focus on overseas or international students

- had focused on further education (vocational)

- had focused on different areas (e.g., screen writing, creative writing, technical writing, songwriting, email writing, resume/cv writing, journalism, or novel)

- had a focus on ACT (US higher education entry exam), A Levels (UK higher education entry exam), the AP exam (US college-level curriculum and exam for high school students), or SATs (US higher education entry exam)

- had a focus on community, home or workplace settings 